\title{
Chapter 8 \\ Cohabitation in Brazil: Historical Legacy and Recent Evolution
}

\author{
Albert Esteve, Ron J. Lesthaeghe, Julián López-Colás, Antonio López-Gay, \\ and Maira Covre-Sussai
}

\section{Introduction}

As in North America and Europe, equally major demographic transitions have taken place in many Latin American countries during the last four decades. Brazil is no exception. Its population is terminating its fertility transition and is even on the brink of sub-replacement fertility (Total Fertility Rate $=1.80$ in 2010), its divorce rate has been going up steadily for several decades in tandem with falling marriage rates (de Mesquita Samara 1987; Covre-Sussai and Matthijs 2010), and cohabitation has spread like wildfire (Rodríguez Vignoli 2005; Esteve et al. 2012a). These have all been very steady trends that have persisted through difficult economic times (e.g. 1980s) and more prosperous ones (e.g. after 2000) alike. There is furthermore evidence from the World Values Studies in Brazil that the country has also been experiencing an ethical transition in tandem with its overall educational development, pointing at the de-stigmatization of divorce, abortion, and especially

\footnotetext{
A. Esteve $(\varangle) \cdot$ J. López-Colás • A. López-Gay

Centre d'Estudis Demogràfics (CED), Universitat Autònoma de Barcelona (UAB),

Bellaterra, Spain

e-mail: aesteve@ced.uab.cat; jlopez@ced.uab.cat; alopez@ced.uab.cat

R.J. Lesthaeghe

Free University of Brussels and Royal Flemish Academy of Arts and Sciences of Belgium,

Brussels, Belgium

e-mail: RLesthaeghe@yahoo.com

M. Covre-Sussai

Universidade do Estado do Rio de Janeiro (UERJ), Rio de Janeiro, Brazil

e-mail: maira.covre@gmail.com 
of euthanasia and homosexuality (Esteve et al. 2012a). These are all features that point in the direction of a so called "Second demographic transition"(SDT) as they have taken place in the wider European cultural sphere and are currently unfolding in Japan and Taiwan as well (Lesthaeghe 2010).

In what follows, we shall solely focus on the rapid spread of unmarried cohabitation as one of the key SDT ingredients. In doing so, we must be aware of the fact that Brazil has always contained several ethnic sub-populations that have maintained a tradition of unmarried cohabitation. By 1970, these were definitely minorities, and Brazil then ranked among the Latin American countries with the lower levels of cohabitation (cf. Esteve et al. 2012a). In fact, Brazil belonged to the same "low cohabitation" group as Uruguay, Argentina, Chile and Mexico. Nevertheless, given an older extant tolerance for cohabitation which was probably larger than in the other four countries just mentioned, we have to take this historical "baseline pattern" fully into account when assessing the recent trends.

In much of the work that follows, we shall concentrate on women in the age group 25-29. At that age virtually all women have finished their education and they have also chosen from a number of options concerning the type of partnership, the transition into parenthood, and employment. Furthermore, the analysis is also restricted to women who are in a union (i.e. marriage + cohabitation), and percentages cohabiting are calculated for such partnered women only.

The analysis is novel in the sense that it includes a much more detailed spatial analysis involving 136 Brazilian meso-regions instead of the classic 26 states (+ the Federal District of Brasilia). This finer geographical grid also permits us to elucidate the weight of the "historical legacy" to a greater extent. For the rest, the cross-sectional analysis for the year 2000 is built along the classic multi-level design, with effects being measured of both the individual characteristics and of the contextual ones operating at the meso-regional level (see also Covre-Sussai and Matthijs 2010). But even more important is the availability of several measurements over time, thanks to the IPUMS data files with large micro-data samples of the various censuses. ${ }^{1}$ This allows for an analysis of changing educational profiles, spatial patterns, and overall levels over time, and solidly steers us away from erroneous extrapolations and interpretations drawn from single cross-sectional differentials. ${ }^{2}$

\footnotetext{
${ }^{1}$ The IPUMS data files contain samples of harmonized individual-level data from a worldwide collection of censuses. See Minnesota Population Center (2014).

${ }^{2}$ The interpretation of the European cohabitation data has greatly suffered from such misinterpretations of educational and social class differentials observed in a single cross-section. The negative "gradients", mostly found in former Communist Europe were typically interpreted as the manifestation of "patterns of disadvantage", whereas measurements over several points in time showed that cohabitation rose - sometimes quite spectacularly - in all social strata, and in several instances even as much among the better than the less educated women.
} 


\section{The Historical Legacy}

As is the case of several other Latin American countries and all Caribbean ones, also Brazil has a long history of cohabitation (Smith 1956; Roberts and Sinclair 1978; for Caribbean: de Mesquita Samara 1987; Borges 1994; de Alzevedo et al. 1999; Holt 2005; for Brazil: Covre-Sussai and Matthijs 2010; Quilodrán 1999, 2008). However, the historical roots of cohabitation are quite distinct for the various types of populations. The indigenous, Afro-Brazilian, and white populations (either early Portuguese colonizers or later nineteenth and twentieth century European immigrants) have all contributed to the diverse Brazilian scene of marriage and cohabitation. A brief review of these contributions will elucidate why the historical roots are of prime importance.

In the instance of the Brazilian indigenous populations, ethnographic evidence shows that they did adhere to the group of populations, which, according to Goody's terminology (1976), lacked diverging devolution of property through women. As shown in Chap. 2 (Table 2.1) for 21 Brazilian indigenous groups (Amazon, Orinoco, Mato Grosso, Highlands and Gran Chaco), none were strictly monogamous, and, if there were exchanges between kinship groups at the occasion of partnership formation, all had exchanges benefitting the wife's kin (bride service or bridewealth) rather than the husband's kin (dowry). Moreover, the majority of them tolerated consensual unions or extra-marital sex. Also the Black and mixed populations, originating from the imported slaves, tolerated consensual or visiting unions and did not engage in passing on any wealth via dowries. The European colonists, by contrast, celebrated their monogamous marriages, followed the dowry system and adhered to social class homogamy. The major caveat, however, is that they often practiced forms of concubinage, either with lower class women or slaves (see for instance Freyre 1933 for Northeastern sugar-cane farmers; for the Bahia colonial upper class in Brazil: Borges 1994 and de Alzevedo et al. 1999). The overall result of these ethnic differences was the creation of a negative relationship between social class and the incidence of consensual unions.

The negative gradient of cohabitation with social class and the stigma attached to consensual unions was enhanced further by mass European immigration during the late nineteenth and twentieth centuries. These migrants to mining areas and to the emerging urban and industrial centers reintroduced the typical Western European marriage pattern with monogamy, institutionally regulated marriage, condemnation of illegitimacy and low divorce. As a consequence the European model was reinforced to a considerable extent and became part and parcel of the urban process of embourgeoisement. This not only caused the incidence of cohabitation to vary according to ethnicity, but also regionally and according to patterns of urbanization and migration. The overall result is that the negative cohabitation-social class gradient is obviously essentially the result of crucial historical developments, and not the outcome of a particular economic crisis or decade of stagnation (e.g. the 1980s and 1990s). 
Nowadays, (since 1996) cohabitation is recognized by law as a type of marriage in Brazil. Cohabiters have the option to formalize the relationship through a contract with the purpose of specifying property divisions. In case of dissolution, the content of the contract is followed. In the absence of a formal contract, the partnership can be considered by the judge as a type of marriage if one of the partners proves that there was an intention to constitute a family, or proves that the couple lived "as a family". In this instance, the same rules apply as for married couples. (Brazil 2002). Furthermore, as of May 2013, Brazil is on the brink of fully recognizing gay marriage as the third and largest Latin American country, i.e. after Argentina and Uruguay which recognized it in 2010. The Brazilian Supreme Court ruled that gay marriages have to be registered in the same way as heterosexual marriages in the entire country, but there is still stiff opposition in Congress coming from Evangelical politicians.

\section{Socioeconomic and Cultural Development}

As stated before, for the Brazilian upper classes the institutions of marriage and the family were historically constructed based on hierarchic, authoritarian and patriarchal relationships, under influence of the Catholic morality. Conversely, men were 'allowed' to have relationships with women from different social and ethnic groups, following different rational and moral codes (Freyre 1933). At the same time, while this patriarchal model described by Freyre serves as a very good illustration of families of sugar cane farmers in the Northeast region of Brazil during the colonial period (sixteenth to the end of nineteenth centuries; de Mesquita Samara 1987, 1997), there was a noteworthy variance in terms of family compositions and roles over different social strata and regions of the country (i.e. Vidal Souza and Rodrigues Botelho 2001; de Mesquita Samara 1997, 1987; Corrêa 1993; de Almeida 1987). It is now well understood by Brazilian social scientists that the influence of the Catholic Church on family life, the patriarchal model of family and gender relations inside the family, all vary considerably across the Brazilian regions, and that this variation is related to both socioeconomic and cultural differences (Vidal Souza and Rodrigues Botelho 2001; de Mesquita Samara 2002). The Brazilian anthropologist Darcy Ribeiro (1995) suggests the following distinctions for the five major areas.

Firstly, the North and Northeast regions have the higher proportions of mixed race populations (pardos: mainly the mixture of native indigenous, European and African descendents), with 68 and $60 \%$ of self-declared pardo in 2011, respectively (IBGE 2013). It was among the upper classe in the Northeast that the family model, described by Freyre (1933) as patriarchal and hierarchic, was more visible. According to Ribeiro (1995), both regions are characterized by a social system stressing group norms and group loyalty.

Secondly, until to the second half of the nineteenth century, the groups in the Southeastern and Southern regions were formed by the union of the Portuguese colonizer with indigenous people and some African slaves. During the colonial period it was from the city of Sao Paulo that expeditions embarked in order to 
explore the mines found in the countryside and to spread the Brazilian population beyond the Tordesillas line. During this period, while husbands went to the countryside, wives took care of children and of the household as a whole. This system fostered less hierarchic family relationships than the ones observed in the North (Vidal Souza and Rodrigues Botelho 2001; de Mesquita Samara 1987, 1997; Corrêa 1993; de Almeida 1987). Today, the descendents of these early settlers in the Southeast and South share their regions with social groups composed of descendents of the large European immigration of the nineteenth and twentieth centuries, especially Italians and Germans. These historical roots explain the contemporary majority of self-declared whites in the South and Southeast (78 and 56\% respectively IBGE 2013).

The last sub-culture identified by Ribeiro (1995) includes people from the inland part of the Northeast and, particularly, from the more rural Central-west area. The Central-West region contains the most equilibrated division of ethnicities in Brazil with $43 \%$ of whites, $48 \%$ of pardos, $7.6 \%$ of African descent and about $1 \%$ of indigenous and Asiatic descent (IBGE 2013). The development of this region started later compared to the coastline and was accelerated, in part, when the country's administrative capital was transferred from Rio de Janeiro to Brasília (Distrito Federal) in 1960. Although this region was relatively unsettled up to that time, the creation of a new city (Brasília was built between 1956 and 1960) spurred population growth and created more heterogeneity and educational contrasts. The rural areas of the Central-West still hold small populations devoted to subsistence agriculture (Ribeiro 1995).

The current socioeconomic development of Brazilian regions is related (among other factors) to different processes of occupation and industrialization. Industrialization and urbanization started earlier and happened faster in Southern regions than in the Northern ones (Guimarães Neto 1998). With the investments realized in recent years, the gap in socioeconomic development among Brazilian regions is reduced, but still evident (IBGE 2012: 168). The North and Northeast regions are the poorest and least developed in the country. These are regions where between 24.9 and $17.6 \%$ of the population were living in extreme poverty, in comparison to 11.6, 6.9 and $5.5 \%$ of the population in the Central-West, Southeast and South (Ipeadata 2010). These two regions also have the lowest values on the Human Development Index of 0.75 and 0.79 for the North and Northeast respectively, whereas the South, the Southeast and Central-West have values of 0.85 and 0.84 (Banco Central do Brasil 2009).

In demographic terms, there is also a significant variation between Brazilian regions. Vasconcelos and Gomes (2012) demonstrated that the demographic transition happened at a different tempo and to a different degree in the five regions. While the Southeast, South and Central-West are found in a more advanced stage of the demographic transition, the North and Northeast showed higher levels of fertility and mortality, as well as a younger age structure (Vasconselos and Gomes 2012). In addition, Covre-Sussai and Matthijs (2010) found that the chances of a couple living in cohabitation instead of being married differ enormously if Brazilian regions and states are compared, and that this variance persists even when socioeconomic and cultural variables are considered. 


\section{The Basic Geography of Cohabitation and Its Major Conditioning Factors}

From the brief picture sketched above, we essentially retain three dimensions that would capture the essence of the historical legacy: (i) the ethnic composition, (ii) the religious mix, (iii) the social class diversity and educational differentials. To this we also added a "frontier" dimension since large parts of western Brazil were settled much later in the twentieth century, and a considerable segment of their population is born outside the region. These dimensions were operationalized using the census definitions as provided by the IPUMS files. Table 8.1 gives the definitions of the categories and the mean of the proportions in the 137 meso-regions as of 2000.

The expected direction of the effects of these dimensions is clear for the racial and religious composition: cohabitation should be lower among Catholics and especially Protestant and Evangelicals than among the others, and the same should hold for whites who traditionally frowned upon cohabitation as lower class behavior. The effect of the frontier should be the opposite as settlements are often scattered and

Table 8.1 Distribution of characteristics of 137 Brazilian meso-regions, measured for women 25-29 as of 2000

\begin{tabular}{|c|c|}
\hline Variables/category & Average of proportions in 137 meso-regions \\
\hline \multicolumn{2}{|l|}{ Cohabitation } \\
\hline Married & 61.5 \\
\hline Cohabitation & 38.5 \\
\hline \multicolumn{2}{|l|}{ Religion } \\
\hline Catholic & 76.0 \\
\hline Protestant Lutheran, Baptist & 03.6 \\
\hline Evangelical & 14.0 \\
\hline No Religion & 4.9 \\
\hline Others & 1.5 \\
\hline \multicolumn{2}{|l|}{ Race } \\
\hline White & 51.0 \\
\hline Brown Brazil (Pardo) & 42.0 \\
\hline Black & 05.1 \\
\hline Indigenous & 1.1 \\
\hline Others & 0.9 \\
\hline \multicolumn{2}{|l|}{ Education } \\
\hline Less than secondary & 76.9 \\
\hline Secondary & 20.0 \\
\hline University & 03.1 \\
\hline \multicolumn{2}{|l|}{ Migrant } \\
\hline Sedentary (Residence in State of birth) & 81.5 \\
\hline Migrant (Residence in other State) & 18.5 \\
\hline
\end{tabular}

Source: Authors' tabulations based on census samples from IPUMS-International 
Table 8.2 Proportions cohabiting among Brazilian women $25-29$ in a union by social characteristics, 2000

\begin{tabular}{|c|c|}
\hline Variables/category & $\begin{array}{l}\text { Proportion } \\
\text { cohabiting }\end{array}$ \\
\hline \multicolumn{2}{|l|}{ Religion } \\
\hline Catholic & 40.8 \\
\hline Protestant Lutheran, Baptist & 23.2 \\
\hline Evangelical & 27.6 \\
\hline No Religion & 62.7 \\
\hline Others & 40.0 \\
\hline \multicolumn{2}{|l|}{ Race } \\
\hline White & 32.4 \\
\hline Brown Brazil (Pardo) & 46.9 \\
\hline Black & 53.6 \\
\hline Indigenous & 59.1 \\
\hline Others & 38.4 \\
\hline \multicolumn{2}{|l|}{ Education } \\
\hline Less than secondary & 44.6 \\
\hline Secondary & 26.4 \\
\hline University & 17.2 \\
\hline \multicolumn{2}{|l|}{ Migrant } \\
\hline $\begin{array}{l}\text { Sedentary (Residence } \\
\text { in State of birth) }\end{array}$ & 38.0 \\
\hline $\begin{array}{l}\text { Migrant (Residence } \\
\text { in other State) }\end{array}$ & 44.0 \\
\hline Total Brazil 2000 & 39.3 \\
\hline
\end{tabular}

Note: The Maps 8.1 and 8.4 represent quartiles of these characteristics

Source: Authors' tabulations based on census samples from IPUMS-International

social control weaker than elsewhere. The role of large cities is however more ambivalent. On the one hand urban life too allows for greater anonymity and less social control, but in the Latin American context, the urban reference group is the wealthier white bourgeoisie and its essentially European pattern of union formation. Then, marriage carries a strong connotation of social success. Moreover, we expect that a more detailed analysis of the patterns among large cities warrants attention as their histories are very diverse. We shall therefore measure each of these metropolitan effects together with those of all the other meso-regions in a subsequent contextual analysis.

Table 8.2 gives the share of women aged 25-29 currently in a union (i.e. married or cohabiting) who are cohabiting according to their religious, educational, racial and migration characteristics, as of the census of 2000. As expected, Protestants (here mainly Lutheran and Baptist) and Evangelicals have by far the lowest proportions cohabiting (see also Covre-Sussai and Matthijs 2010). Catholics and "other" (here including a heterogeneous collection of Spiritist and of Afro-brazilian faiths) have a similar incidence, but also markedly lower levels than the category "no religion". 


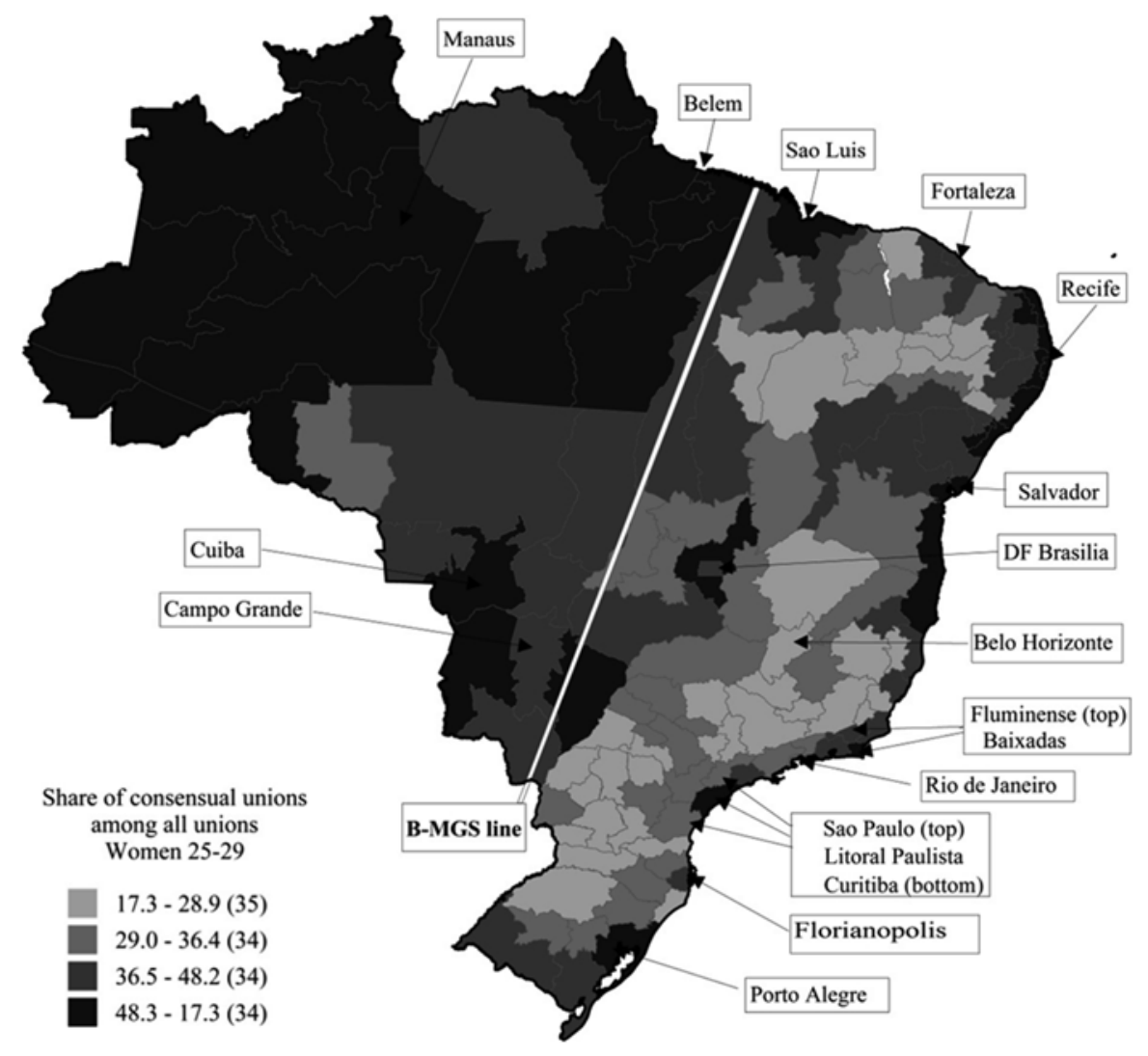

Map 8.1 Proportions cohabiting among women 25-29 in a union; Brazilian meso-regions 2000 (Source: Authors' elaboration based on census samples from IPUMS-International)

The racial distinctions are completely as expected, with whites and "others" (i.e. mainly Asians) having the lower proportions cohabiting, the indigenous and black populations the highest, and the mixed "Pardo" population being situated in between. The educational gradient is still very pronounced with only $17 \%$ of partnered university graduates in cohabitation against $44 \%$ among partnered women with primary education only and $39 \%$ for the whole of Brazil. Finally, the incidence of cohabitation among migrants is indeed higher than among non-migrants, but the difference is only 6 percentage points.

As far as cohabitation is concerned, there are three major zones in Brazil. Firstly, the areas west of the "Belem - Mato Grosso do Sul" line (see Map 8.1, dotted line marked "B-MGS") virtually all fall in the top two quartiles, and the majority even in the highest quartile with more than $48 \%$ cohabiting among partnered women 25-29. This is also a huge area with low population densities. The second region with similarly high percentages cohabiting stretches along the Atlantic coast, from Sao Luis in the North to Porto Alegre in the South. However, it should be noted that Rio de Janeiro is only in the second quartile. The third zone forms an inland 
North-South band, with a majority of meso-regions having percentages below the median (36\%). There are, however, a few notable exceptions such as the Rio Grandense regions along the Uruguay border, the Baiano hinterland of Salvador de Bahia (former slave economy), and the broader area of the Federal capital of Brasilia (large immigrant population). By contrast, the zones in this hinterland band in the lowest quartile, i.e. with less than $29 \%$ of partnered women 25-29 in cohabitation, are Pernambuco to Tocantins stretch in the North, Belo Horizonte and the whole of Minas Gerais in the center, and most of the "white" South. Virtually all of the remaining areas of the band are in the second quartile.

The spatial patterning of religious groups is given in the four sections of Map 8.2. The Catholics are a large majority (over $85 \%$ ) in three areas east of the

Catholic

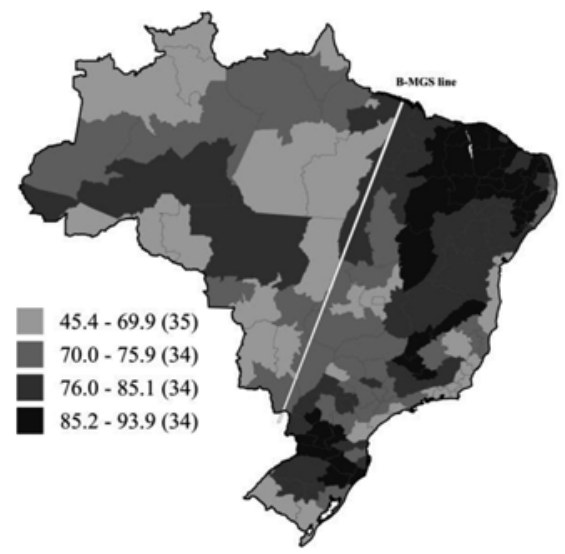

Evangelical

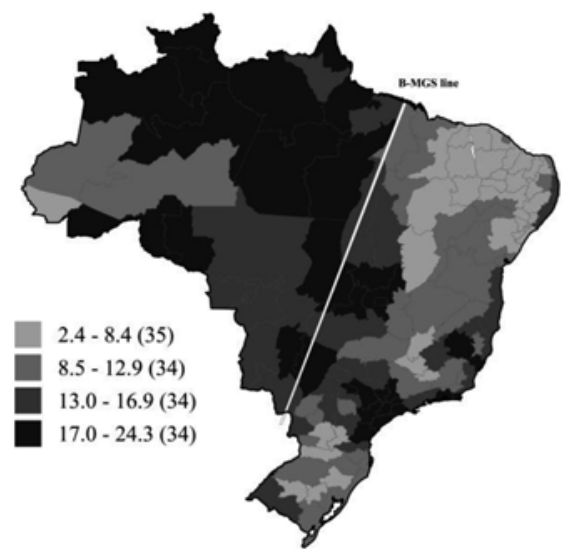

Protestant Lutheran Baptist

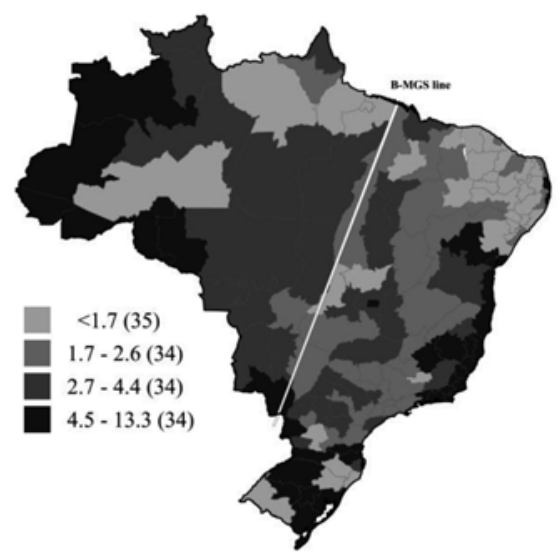

No religion

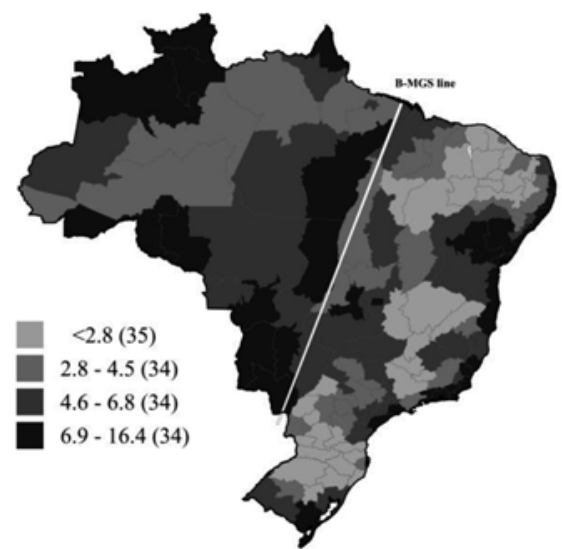

Map 8.2 Proportions in various religious groups, women 25-29; Brazilian meso-regions 2000 (Source: Authors' elaboration based on census samples from IPUMS-International) 
"Belem - Mato Grosso do Sul" (B-MGS) line: (i) a broad area centered around Pernambuco, Piaui and Eastern Baiana, (ii) a stretch in central Minas Gerais, and (iii) much of the Catarinense and Paranaense in the South. To the west of the B-MGS line there is an important concentration of Evangelicals (upper quartile $=21-35 \%$ ) and no religion or other religion (upper quartile $=8-18 \%$ ), whereas Spiritists and Afro-brazilians are rare. To the east of the SL-MG line, lower proportions Catholic are compensated by Evangelicals in three smaller areas: (i) meso-regions around Brasilia, (ii) the southern Bahia, Spirito Santo and Rio de Janeiro coast, and (iii) central Sao Paulo. The Spiritist and Afro-brazilian group is much smaller and the upper quartile only ranges from 2 to $8 \%$ of young women in 2000 . They are predominantly found in (i) Metropolitan Recife and Salvador, (ii) the central band from Espirito Santo/Rio to the Mato Grosso, and in (iii) Florianapolis and southern Rio Grande do Sul. The group without or other religions is somewhat larger and the upper quartile reaches 6-18\%. They are located along the Atlantic Ocean from Recife to the Paulista coast, in Brasilia and western Minas Gerais, and finally again in the Rio Grandense south.

The racial composition is presented in the four sections of Map 8.3, which immediately highlights the strong degree of spatial clustering. The white population forms a large majority of more than $70 \%$ in the four southern states of Sao Paulo, Parana, Santa Catarina and Rio Grande do Sul and in the south of Minas Gerais. The black population forms a similarly large majority in the North-East from the Sao Luis coast and running further south via an inland stretch to Sergipe, Bahia, eastern Minas Gerais, Espirito Santo and Rio de Janeiro. Two much smaller clusters are found along the Porto Alegre coast, and at the other extremity of the country in Acre.

The indigenous population is very largely located to the west of the SL-MGS line, but is also to be found in scattered areas of Bahia, Minas Gerais, the Paulista coast and in eastern Parana. Finally, the important mixed race population (often referred to as "Pardo") form a majority in all the Northern regions, with the exception of the Ceara-Pernambuco-Alagoas corner. Wherever whites are a majority of over $70 \%$, as in the South, the mixed race population obviously falls below $25 \%$ (lowest quartile), but it is still the second largest group.

The three sections of Map 8.4 show the educational distribution. Many of the areas in the North with a majority of black, indigenous and mixed race populations also show up on the map of the population with no more than primary education. Apart from this contiguous zone of low education, including the central Baiano, there is no other area in the country that falls in this category, except again eastern Parana with a more important indigenous population. Still in the "Norte" and "Nordeste", the top quartile of secondary education mainly contains the large urban meso-regions, such as Manaus, Belem, Sao Luis, Fortaleza, Recife and Salvador, and of them only Recife makes it to the top quartile of university level education. The story for the Center and the South is completely the opposite, with many mesoregions making it to the top quartiles of secondary and/or university education. With respect to the latter, the regional cities and the large urban areas with institutions of higher learning are standing out, in the Mato Grosso and Goias as well as in the main parts of Minas Gerais and the South. Hence, the spatial distributions of race and education show a marked degree of correlation. 
White

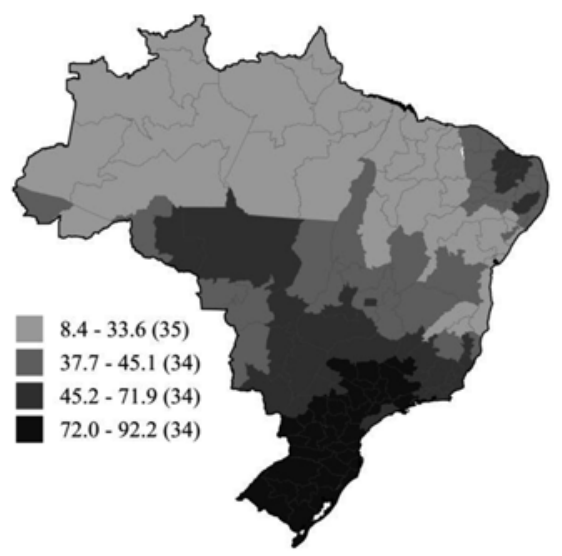

Indigenous

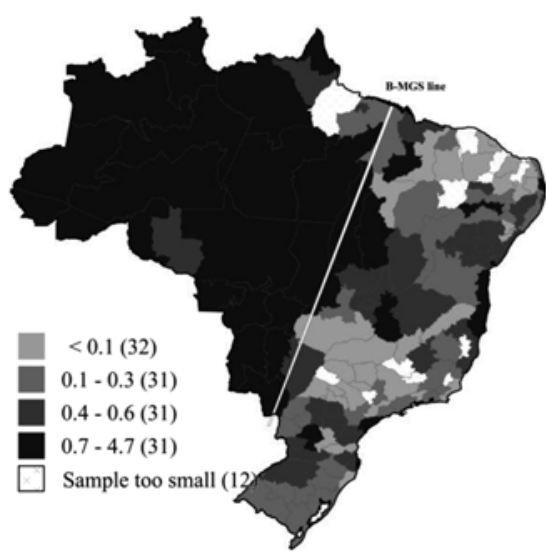

Black

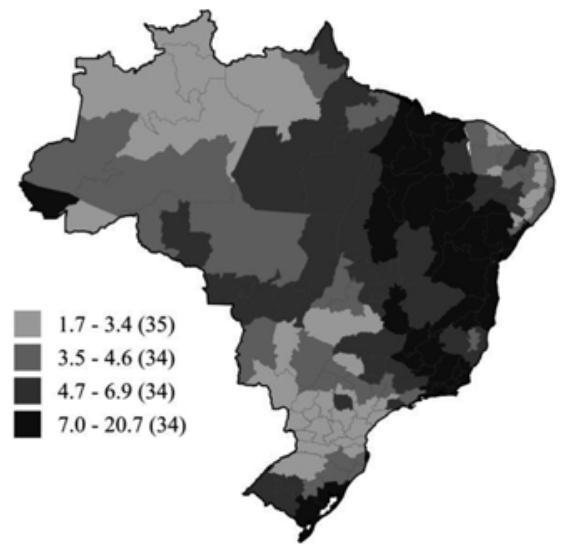

"Brown" (Pardo)

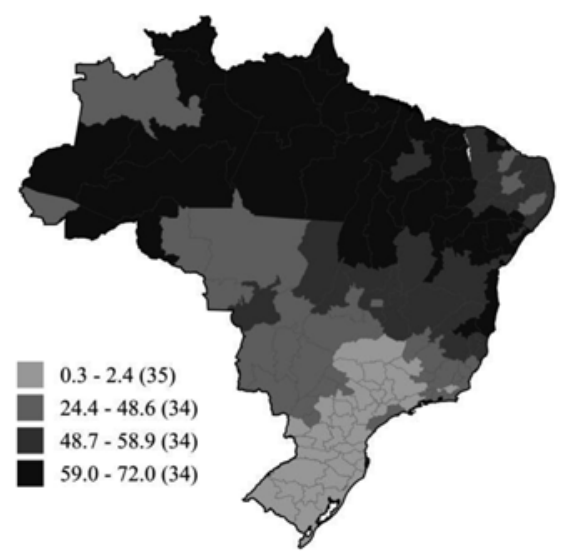

Map 8.3 Proportions in various racial categories, women 25-29; Brazilian meso-regions 2000 (Source: Authors' elaboration based on census samples from IPUMS-International)

\section{Explaining the Levels of Cohabitation as of the Year 2000}

The harmonized IPUMS microdata files for Brazil cover the period up to the census of 2000. The percentages cohabiting among women 25-29 currently in any union for 2010 is also available from IBGE, but not the essential individual-level covariates. Hence, the statistical models are only constructed for the year 2000 at this point. The 2000 sample used here contains just over 4.6 million women 25-29 currently in a union, which is about $6 \%$ of the total in Brazil.

The statistical method is that of contextual logistic regression. A very similar method was used by Covre-Sussai and Matthijs (2010), using the larger Brazilian states as spatial units instead of the micro-regions used here (see Map 8.1). Other 
Less than secondary

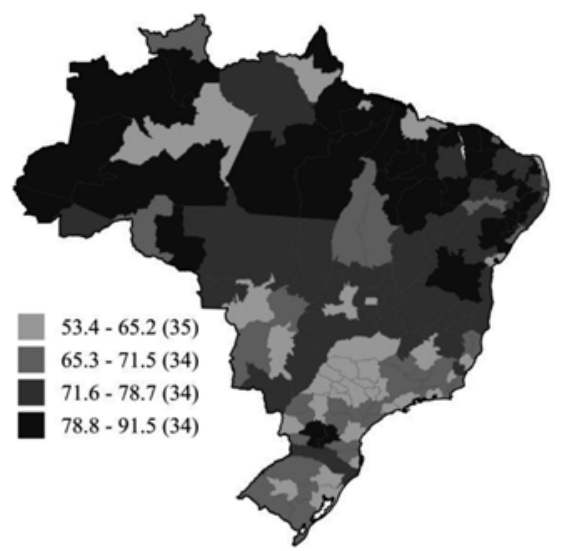

Secondary

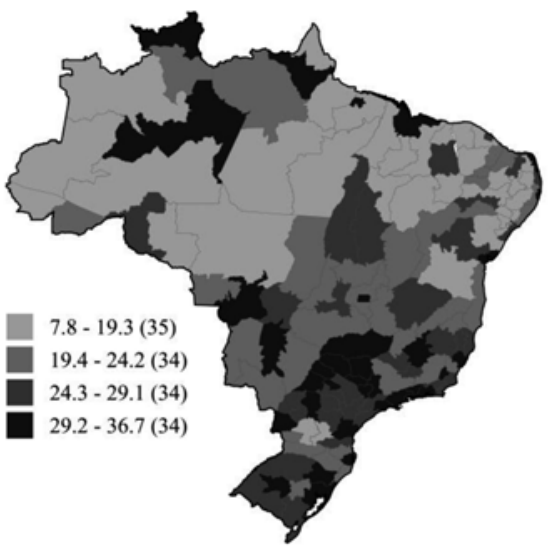

University

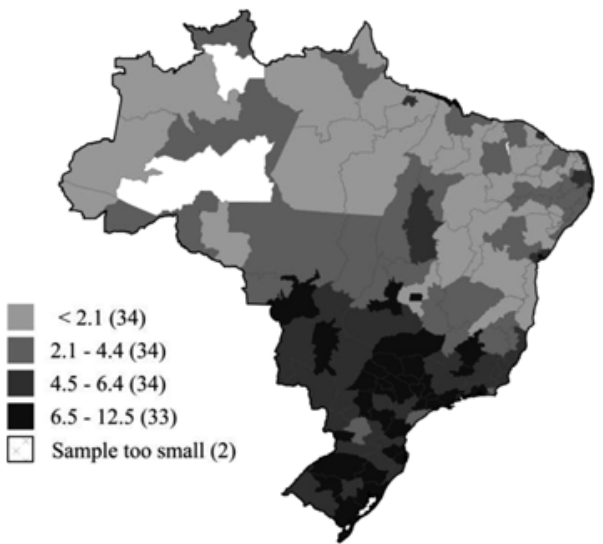

Map 8.4 Proportions in three education categories, women 25-29; Brazilian meso-regions, 2000 (Source: Authors' elaboration based on census samples from IPUMS-International)

major differences compared to the present analysis is that these authors used a sample of couples of all ages, with individual characteristics being available for both men and women. Hence they could refine their categories by combining the information for each partner or spouse. In addition they have income and education as separate indicators. And given their much broader age range they also needed to include the number of children and the birth cohort of men stretching as far back as the 1920 s.

Our dataset consists of individuals (women 25-29 in union) nested within mesoregions. We model the probability of partnered women to be in a cohabiting union (as opposed to being married). We include explanatory variables at the individual level (e.g. education, race, religion) and at the meso-regional level (e.g. \% Catholics, $\%$ whites). To this end, multilevel models recognize the hierarchical structure and 
are able to exploit hierarchically arranged data to differentiate the contextual effects from background effects for individuals. In particular, we use a two-level random intercept logistic regression model. Level 1 is the individual $(i)$ and level 2 is the meso-region $(j)$. In this model the intercept consists of two terms: a fixed component, $\beta_{0}$, and a random effect at level $j$ (meso-region) $\mu_{0 j}$. The model assumes that departures from the overall mean $\left(\mu_{0 j}\right)$ are normally distributed with mean zero and variance of $\sigma_{u 0}{ }^{2}$. Therefore, meso-regions are not introduced into the models using fixed effects (i.e. including dummy variables for each of the 136 meso-regions in Brazil). Instead, we use the $\sigma_{u 0}{ }^{2}$ parameter to measure the variance across mesoregions. In the models that follow we use this variance as an indicator of the degree to which the introduction of individual-level variables as controls is capable of reducing the differences between the meso-regions. Normally, this variance should shrink as more and better individual-level predictors are introduced. If this is not so, then substantial spatial differences are persisting independently of the individuallevel controls.

In Table 8.3 the results are given in the form of odds ratios (OR) of cohabiting relative to a reference category (value of unity) of the individual-level determinants. Model 1 is the "empty" model, but it estimates the variance between de mesoregions when there are no controls for the individual-level covariates. We start out with introducing religion and then add in race, and subsequently education and migrant status of the individuals. As can be seen, the odds ratios are very stable, and all in the expected direction. Compared to Catholics, the odds of cohabiting is much smaller among partnered Protestants and Evangelicals $(\mathrm{OR}=0.43$ and 0.44 in model 5). By contrast, the odds is higher among "Others" (including Spiritists and Afrobrazilians (1.12), and much higher among persons without religion or of another faith (1.92)). Compared to partnered whites, indigenous and black women are roughly twice as likely to cohabit (2.14 and 1.98$)$. The Pardo women are having risks that are more modest $(\mathrm{OR}=1.47)$, and other races resemble the whites $(1.19)$. Not surprisingly, the educational gradient is steep, with lower educated partnered women being four times more likely to cohabit than partnered women with a university education ( $\mathrm{OR}=4.02)$. Partnered women $25-29$ with secondary education are also more likely to cohabit compared to those with a tertiary education (1.72). Finally, as expected, residence in another state increases the odds ratio, but only modestly so $(\mathrm{OR}=1.27)$.

None of these findings come as a surprise given the historical context of patterns of partnership formation in Brazil, and our findings are entirely in line with those of Covre-Sussai and Matthijs (2010). Given the much broader age group used in their sample, they are also capable of illustrating a very marked rise in cohabitation over marriage for each successively younger generation.

The more striking result of the analysis in Table 8.3 is that the variance between states is not reduced by the introduction of controls for individual-level characteristics. Clearly there are robust effects strictly operating at the regional level that continue to carry a substantial weight. Another way of showing this is to plot the meso-region effects (i.e. random part of the intercept) of Model 5 with all individual level predictors against the "empty" Model 1 effects without these controls. 
Table 8.3 Estimated odds ratios from a multilevel logistic regression model of unmarried cohabitation among partnered women 25-29 by social characteristics, Brazil 2000

\begin{tabular}{|c|c|c|c|c|c|}
\hline Category & Model 1 & Model 2 & Model 3 & Model 4 & Model 5 \\
\hline \multicolumn{6}{|l|}{ Religion } \\
\hline Protestant Lutheran, Baptist & & 0.39 & 0.40 & 0.41 & 0.43 \\
\hline Evangelical & & 0.50 & 0.47 & 0.44 & 0.44 \\
\hline No religion & & 2.06 & 2.00 & 1.91 & 1.92 \\
\hline Others & & 0.84 & 0.87 & 1.12 & 1.12 \\
\hline Catholic (ref.) & & 1 & 1 & 1 & 1 \\
\hline \multicolumn{6}{|l|}{ Race } \\
\hline Black & & & 2.27 & 1.97 & 1.98 \\
\hline Brown Brazil & & & 1.67 & 1.47 & 1.47 \\
\hline Indigenous & & & 2.46 & 2.11 & 2.14 \\
\hline Others & & & 1.16 & 1.19 & 1.19 \\
\hline White (ref.) & & & 1 & 1 & 1 \\
\hline \multicolumn{6}{|l|}{ Education } \\
\hline Less than Secondary & & & & 4.07 & 4.02 \\
\hline Secondary & & & & 1.72 & 1.72 \\
\hline University (ref.) & & & & 1 & 1 \\
\hline \multicolumn{6}{|l|}{ Migrant } \\
\hline Residence in another State & & & & & 1.27 \\
\hline Residence in State of birth (ref.) & & & & & 1 \\
\hline Variance left between meso-regions & 0.32 & 0.34 & 0.30 & 0.34 & 0.32 \\
\hline Intercept & -0.50 & -0.41 & -0.68 & -1.82 & -1.85 \\
\hline
\end{tabular}

Notes: Regression coefficients are reported in the appendix Table 8.7. All regression coefficients are statistically significant at the 0.0001 level

Source: Authors' tabulation based on census samples from IPUMS-International

This scattergram is presented in Fig. 8.1 and it clearly shows that controls for all individual-level variables do not change the map of cohabitation versus marriage among women 25-29.

In order to elucidate these regional effects, a Model 6 was tested with a typology of meso-regional characteristics being added. After exploring various possibilities, we settled for a contextual variable made up of eight categories of combinations of the following three variables: percentage Catholic in the meso-region, the percentage white and the percentage with more than secondary education. Each of these were dichotomized and split at their median. The median values for the 137 mesoregional values were 0.77 for proportions Catholic, 0.46 for proportions white and 0.15 for proportions with at least secondary education. The variables are respectively indicated by $\mathrm{C}, \mathrm{W}$ and $\mathrm{S}$. We use upper cases if the meso-region value is equal or above the median, and lower cases if it is below. The eight categories then range from CWS to cws, with all the other combinations in between, and together they form this meso-regions typology. The results with this contextual information being added to the regression are given in Table 8.4 (Model 6). 


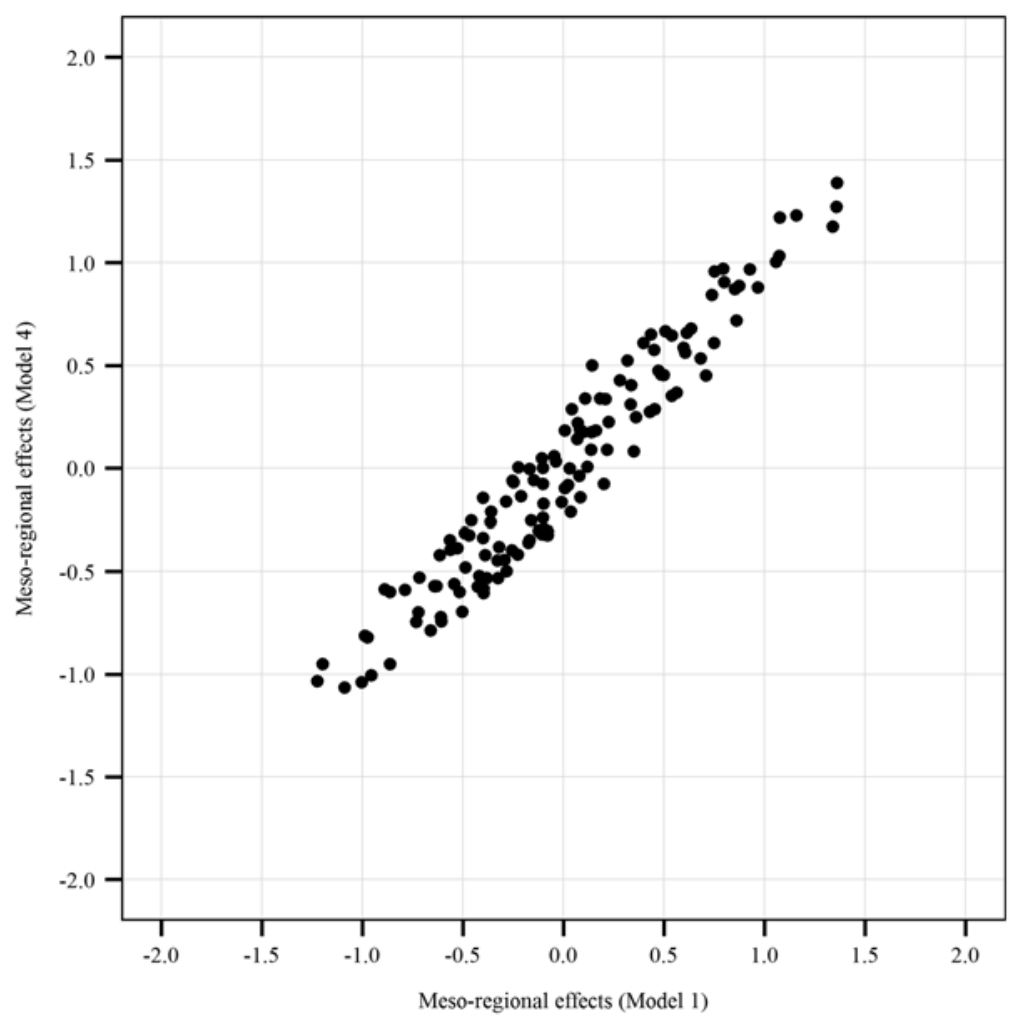

Fig. 8.1 Plot of the meso-region effects of the model with all individual-level variables against those of the "empty" model 1 (Source: Authors' elaboration based on census samples from IPUMS-International)

In Model 6 the odds ratios for the individual-level variables are identical to those of Model 5, but the addition of the eight meso-regional types clearly reduces the variance of the random parts of the intercept, roughly from 0.30 to 0.19 . This means that residence in any of the types helps in accounting for a woman's status as being in cohabitation rather than in a marriage. Taking CWS as the reference category, residence in the $\mathrm{cwS}$ meso-regions increases the odds ratio the most (3.67), followed by residence in the cws and the $\mathrm{CwS}$ regions $(\mathrm{OR}=2.41$ and 2.12). A more modest effect is noted for the cWS and the cWs regions, whereas the Cws and the CWs meso-regions are not different from the CWS reference category. ${ }^{3}$

\footnotetext{
${ }^{3} \mathrm{~A}$ Boolean minimization performed for these eight combinations and predicting their level of cohabitation being either above or below the overall median for all meso-regions produces similar results, which are easily interpretable. The combinations that fall below the median are:
}

$$
\begin{aligned}
& \mathrm{Coh}<\mathrm{Me}=\mathrm{C}(\mathrm{W}+\mathrm{s})+\mathrm{WS} \\
& \text { or } \\
& \mathrm{Coh}<\mathrm{Me}= \mathrm{CW}+\mathrm{Cs}+\mathrm{WS}
\end{aligned}
$$


These eight combinations can be reduced to four:

1. the "very low" group of meso-regions which are all more strongly Catholic and who are made up of three types $(\mathrm{Cws}+\mathrm{CWS}+\mathrm{CWs}$, or $\mathrm{CW}+\mathrm{Cws})$ and which have relative risks in Model 6 comprised between 1.000 and 1.126,

2. a "moderately low" group which is white and less Catholic (cWs $+\mathrm{cWS}$, or simply $\mathrm{cW}$ ) with relative risks of 1.353 and 1.580 ,

3. a "moderately high" group with two non-white types ( $\mathrm{CwS}$ and cws) and relative risks of 2.120 and 2.408 respectively,

4. and finally a "very high group" with the cwS type only and a relative risk of 3.673.

These four types are reproduced on Map 8.5, with the number of meso-regions in each of the categories mentioned between parentheses.

The main demarcations are again clear. The highest group cwS is composed of mainly urban areas to the west of the B-MGS line or along the Atlantic coast. The same holds for the next highest group with a predominantly non-white population. At the other end of the distribution, the lowest group of more strongly Catholic meso-regions stands out, with the $\mathrm{CW}$ combination in the south and the Cws combination in the North-East.

i.e. meso-regions tend to be below the median level of cohabitation among partnered women 25-29 when they exhibit the following combinations of just two characteristics, i.e. they are either Catholic and white(CW), or Catholic and lower education (Cs), or white and higher education (WS).

A linear decomposition of conditional probabilities of cohabiting using 4 dichotomized predictors, i.e. for the 16 combinations, gives the following average net effects for the contrasts:

$$
\begin{aligned}
& \mathrm{C}-\mathrm{c}=-0.56 \\
& \mathrm{~W}-\mathrm{w}=-0.67 \\
& \mathrm{~S}-\mathrm{s}=+0.11 \text { (but interaction with } \mathrm{w} \text { ) } \\
& \mathrm{M}-\mathrm{m}=-0.09
\end{aligned}
$$

This means that, across the three other dichotomies, the average difference in cohabitation percentages between the more Catholic and the less Catholic areas (C-c) is 56 percentage points less cohabitation in the areas with the $\mathrm{C}$ condition. Similarly, such a strong contrast is found for white versus non-white areas, with the former having on average 67 percentage points fewer cohabiting women. The contrast for the migration variable (M-m) is very small and negligible. However, the education contrast goes in the opposite direction from what is expected. This is entirely due to the $\mathrm{wS}$ and ws combinations: in non-white areas, cohabitation among young women is MORE prevalent in the better educated meso-regions than in the less educated ones. This may reflect the fact that non-white better educated women are starting partnerships much later, and therefore have a greater likelihood of still being in the premarital cohabitation phase. However, it should be noted that this is only so if the non-white condition (i.e. w) is met as well. In white areas (i.e. W), the educational contrast is smaller and goes in the expected direction, i.e. more cohabitation in the $\mathrm{s}$ than in the $\mathrm{S}$ categories.

${ }^{4}$ The fact that the cwS group of meso-regions has the highest relative risk is concordant with the finding mentioned in the previous footnote, i.e. that non-white and not predominantly catholic areas with more better educated women have higher cohabitation rates possibly because of these women delaying partner selection to a greater extend. 
Table 8.4 Estimated odds ratios from a multilevel logistic regression model of unmarried cohabitation among partnered women 25-29, Brazil multilevel logistic regression results for proportions cohabiting among women 25-29 in a union by type of meso-region, Brazil 2000

\begin{tabular}{l|r}
\hline Catholic - White - Secondary (CWS) (ref.) & 1 \\
\hline Catholic - No White - No Secondary (Cws) & 1.12 \\
\hline Catholic - No White - Secondary (CwS) & 2.11 \\
\hline Catholic - White - No Secondary (CWs) & 1.13 \\
\hline No Catholic - No White - No Secondary (cws) & 2.40 \\
\hline No Catholic - No White - Secondary (cwS) & 3.67 \\
\hline No Catholic - White - No Secondary (cWs) & 1.35 \\
\hline No Catholic - White - Secondary (cWS) & 1.58 \\
\hline Individual level variables: same relative risks as in Model 5 & \\
\hline Variance among meso-regions & 0.19 \\
\hline Intercept & -2.26 \\
\hline
\end{tabular}

Notes: Odds ratios for individual variables same as in Model 5. Regression coefficients of the full model are reported in the appendix Table 8.7. All regression coefficients are statistically significant at the 0.0001 level

Source: Authors' tabulations based on census samples from IPUMS-International

The conclusions concerning the differentials in levels of cohabitation among partnered women 25-29 as of the year 2000 are, first and foremost, that the historical patterns are still very visible, and that the racial and religious contrast are by far the two dominant ones. Moreover, these characteristics are operating both at the individual and the contextual level and in a reinforcing fashion. In other words, whites in predominantly white or Catholic meso-regions are even less likely to cohabit than whites elsewhere, whereas non-whites in non-white or less Catholic meso-regions are much more like to cohabit than non-whites elsewhere. The force of history and its concomitant spatial patterns clearly still formed the "baseline" onto which the more recent developments are being grafted.

\section{Recent Trends}

We are able to follow the trends in cohabitation among partnered women 25-29 for the period 1974-2010 by level of education and for the period 1980-2010 by municipality and by meso-region. These data are based on the IPUMS census samples and on IBGE data for 2010, and eloquently show the extraordinary magnitude of the Brazilian "cohabitation boom".

The evolution by education is presented on Fig. 8.2. Since social class and education differences are closely correlated in Brazil, these percentages duly reflect the rise in cohabitation in all social strata since the 1970s. 


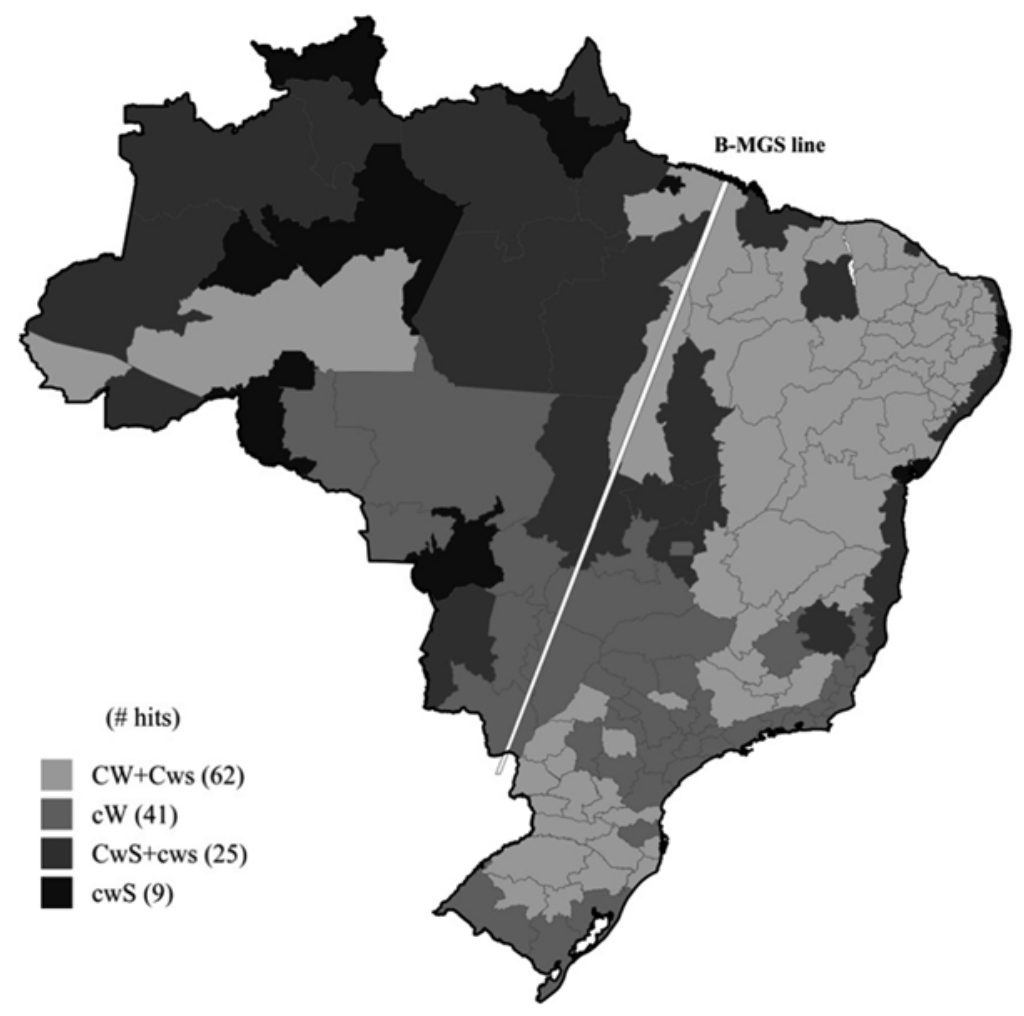

Map 8.5 The four types of meso-regions distinguished according to their relative risk of cohabitation for partnered women 25-29, 2000 regions (legend: see text) (Source: Authors' elaboration based on census samples from IPUMS-International)

More specifically, the 1970 results can be taken as a "historical baseline" against which the subsequent evolution can be evaluated. A rather striking feature of this initial cohabitation profile by education is that consensual unions by no means constituted the dominant union type among the lesser educated women: less than 10\% of such women were cohabiting in $1970 .{ }^{5}$ This is a strikingly low figure compared to the incidence of cohabitation among such women in the northern Andean countries and in many of the Central American ones. It reveals that, apart from northern coastal towns and areas to the west of the B-MGS line, cohabitation was not at all a common feature, not even among the lower strata of the population. But, from the mid-70s onward, there is a remarkably steady trend to much higher levels. Initially, the rise is largest among the women with no more than partial or complete primary education, who both exceed the $20 \%$ level by 1991 . After that date, however, women

${ }^{5}$ The share of cohabitation among all partnered women in a union as of the 1960 census was only $6.45 \%$. 


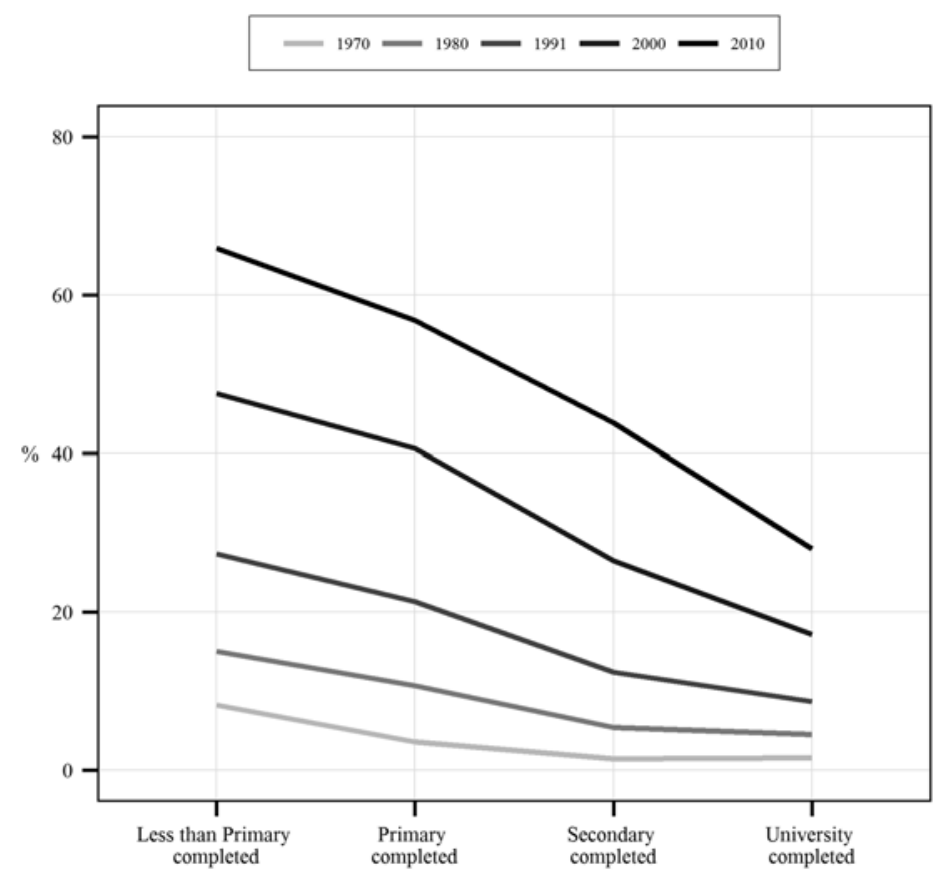

Fig. 8.2 Percent cohabiting among partnered women 25-29 by education, Brazil 1970-2010 (Source Authors' elaboration based on census samples from IPUMS-International)

with completed secondary education are rapidly catching up, and shortly thereafter women with a university education follow as well. The overall result by 2010 is clear: the educational gradient of cohabitation remains negative throughout, but the levels shift up in a very systematic fashion among all social strata. Cohabitation is now no longer the prerogative of the lesser educated women. And by extension, it is no longer an exclusive feature of the non-white population either. Moreover, it is most likely that the upward trend will continue in the near future, and that the negative education gradient will become less steep as well.

The availability of six successive censuses, i.e. from 1960 to 2010, also offers the possibility of following cohort profiles by education. These are shown in Fig. 8.3. There are two issues here: (1) The cohort layering and the pace of change, and (2) the slope of each cohort line over time. There has been a steady cohort-wise progression of cohabitation, with successive accelerations for each younger cohort compared to its immediate predecessor. That is abundantly clear for all levels of education, and the lower educated ones obviously lead the way. This is not surprising and perfectly consistent with the evolution of the cross-sectional profiles shown in Fig. 8.2. But when inspecting cohort tracks between ages 20 and 50, an interesting feature emerges: most of the cohorts have upward slopes. This is caused by the rapid increases in percentages cohabiting during the period 1990-2010. Evidently, before that period the progression of cohabitation was slow among the older cohorts when 


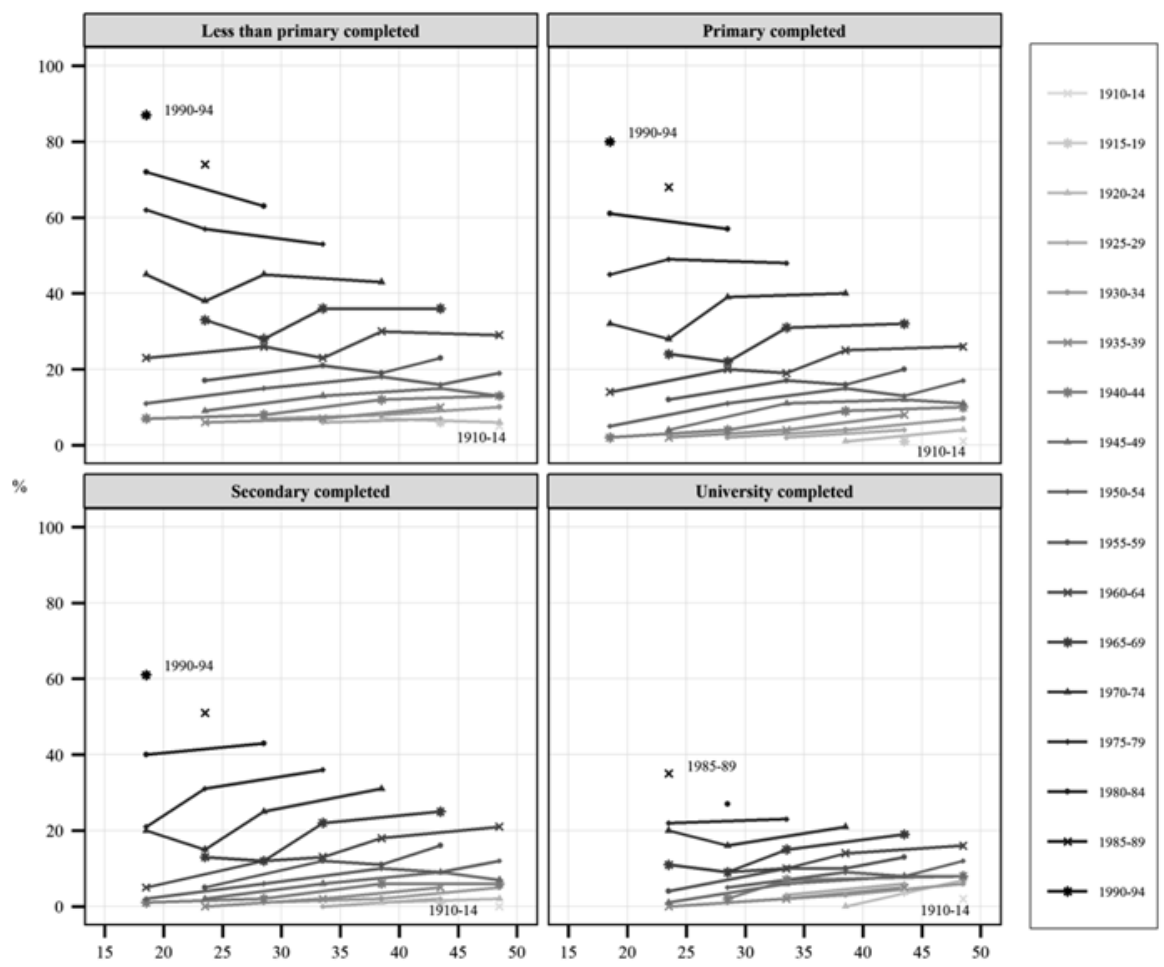

Fig. 8.3 Birth-cohort profiles of the share of cohabitation among partnered women up till age 50 by level of education. Brazilian cohorts born between 1910 and 1995 (Source: Authors' elaboration based on census samples from IPUMS-International)

they started out, but later on their shares of cohabitation grew when they reached older ages, i.e. between 30 and 50. This remarkable later age "catching up" is found at all educational levels, Brazilian university graduates included. It is only when younger incoming cohorts born after 1975 are reaching much higher starting levels that the slopes reverse, and that cohabitation may be more frequently converted into marriage before age $30-34$. There is also the possibility of a selection effect, because the composition of those in a union at age 20 may not be identical to those in a union at age 30 . The final caveat is that the stability of the aggregate percentage cohabiting across ages does not imply longer term cohabitation with the same partner. Frequent partner change within the same type of union would also produce flat cohort profiles for that type.

The spatial pattern is equally worthy of further investigation. In Fig. 8.4 we have ordered the meso-regions according to their percentage of partnered women 25-29 in cohabitation as of 1980. That plot shows that a large majority of meso- 


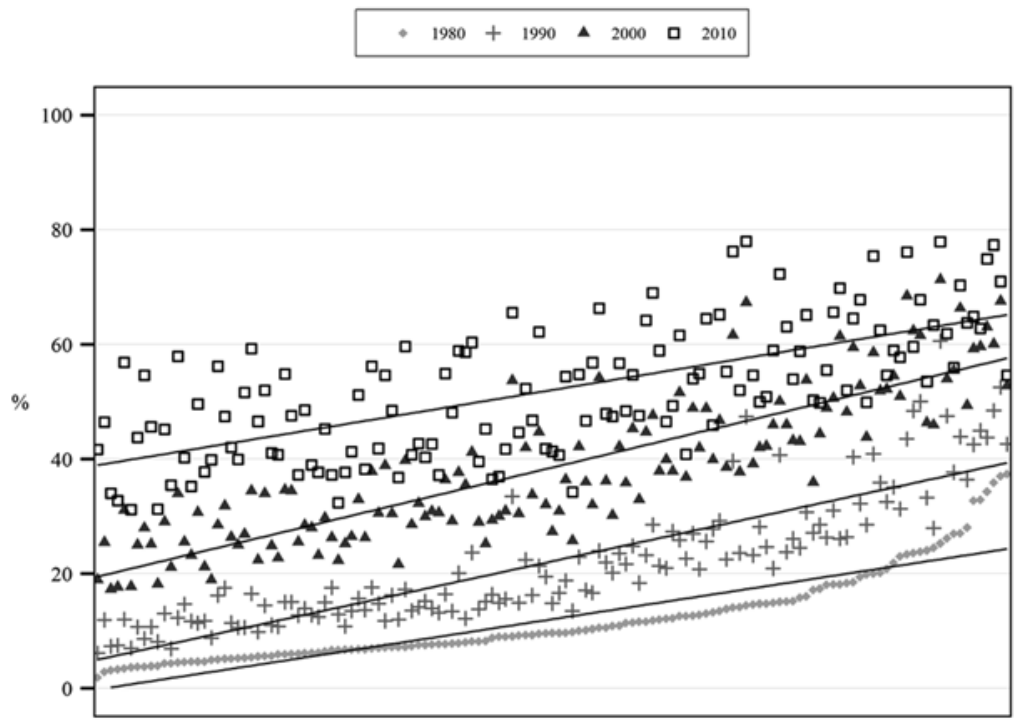

Fig. 8.4 Increase in the percentages cohabiting among all partnered women 25-29 in Brazilian meso-regions: 1980 (bottom), 1990, 2000 and 2010 (top) (Source: Authors' elaboration based on census samples from IPUMS-International)

regions did not have levels of cohabitation exceeding $20 \%$ as of that date, but also that the outliers exceeded $30 \%$. By 1990, there is a universal increase of cohabitation, but the vanguard regions of 1980 exhibit the larger increments, and several of them reach $50 \%$. Between 1990 and 2000, there is a further increase by on average about 15 percentage points, and this increment is fairly evenly observed for the entire distribution of meso-regions. The vanguard areas now exceed the $60 \%$ level, but the areas at the tail also pass the $20 \%$ mark. The last decade, however, is characterized by a typical catching up of the meso-regions at the lower end of the distribution. For these, the increment is on average close to 20 percentage point, whereas the increment is about half as much for the vanguard regions. As of 2010 no regions are left with less than $30 \%$ cohabitation, and the upper tail is about to reach the $80 \%$ level.

A much more detailed view is also available by municipality for the last decade, and these maps are being shown in the appendix (Map 8.6). The main features are: (1) the further advancement in all areas to the west of the B-MGS line, (2) the inland diffusion from the Atlantic coast in the North, and (3) the catching up of the southern states of Rio Grande do Sul and Santa Catarina. 
2000

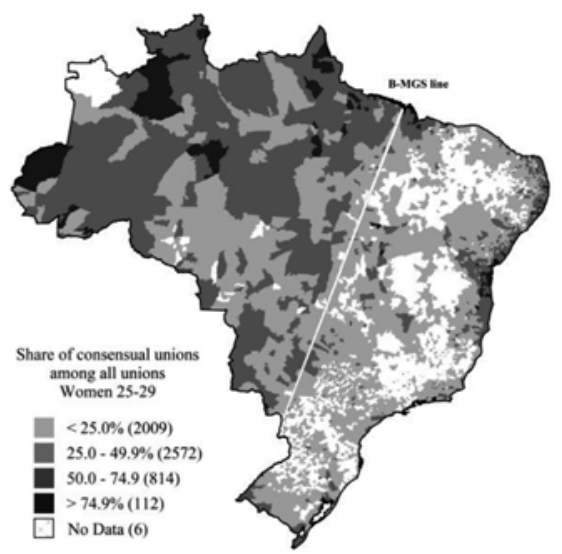

2010

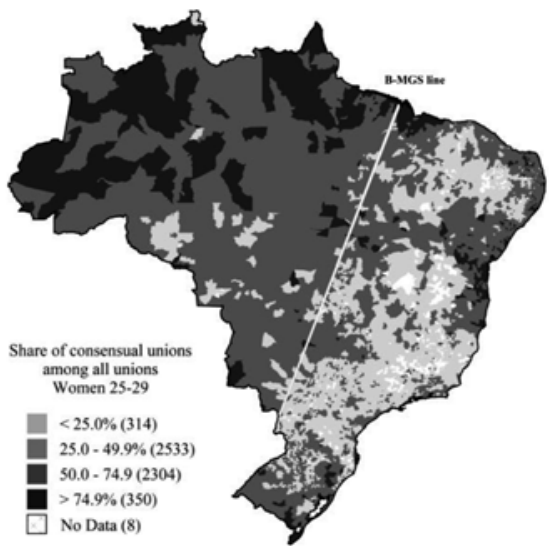

Map 8.6 Percent cohabiting among all partnered women 25-29 in Brazilian municipalities, 2000 and 2010 (Source: Authors' elaboration based on census samples from IPUMS-International)

\section{Further Examination of the Spatial Trends in 136 Meso-Regions, 1980-2010}

In this section we will examine the relative pace of the change in proportions cohabiting among women in a union aged 25-29 over the 30 year period between 1980 and 2010, using the meso-regions and their characteristics as of the year 2000. To this end, the following covariates were constructed for women 25-29: (i) the percentage Catholic, (ii) the percent white, (iii) the percent with full secondary education or more, (iv) the percentage immigrants, i.e. born out-of- state, and (v) the percentage urban (Brazilian census definition). We shall also use two different measures of change. The first one is the classic exponential rate of increase, whereas the second one is a measure that takes into account that a given increment is more difficult to achieve for regions that already covered more of the overall transition to start with than for regions which at the onset of the measurement period still had a longer way to go. This measure will be denoted as "Delta Cohabitation", and it relates the gains in a particular period to the total gains that could still be achieved.

The classic rate of increase is defined as:

$$
\text { r30 }=\ln (\text { Cohab2010 } / \text { Cohab1980 })
$$

And the Delta30 measure as:

$$
\text { Delta30 }=(\text { Cohab } 2010-\text { Cohab 1980 }) /(0.950-\text { Cohab 1980 })
$$


Table 8.5 Prediction of the increase in cohabitation among partnered women 25-29 in the meso regions of Brazil, period 1980-2010: standardized regression coefficients and R squared (OLS)

\begin{tabular}{l|l|l|c}
\hline Covariates in 2000 & r30 & r30 with Cohab 1980 & Delta30 \\
\hline$\%$ w. Catholic & 0.66 & 0.22 & $-0.15 \mathrm{~ns}$ \\
\hline$\%$ w. White & 0.42 & $0.11^{*}$ & $-0.26^{* *}$ \\
\hline$\%$ w. Secondary educ. & $0.12 \mathrm{~ns}$ & $0.06 \mathrm{~ns}$ & $0.04 \mathrm{~ns}$ \\
\hline$\%$ w. Migrant & $0.07 \mathrm{~ns}$ & $-0.03 \mathrm{~ns}$ & $0.01 \mathrm{~ns}$ \\
\hline$\%$ w. Urban & $-0.32^{*}$ & $-0.22^{*}$ & $-0.37^{*}$ \\
\hline$\%$ w. Cohab 1980 & Not used & -0.68 & Not used \\
\hline$R$ squared & 0.65 & 0.85 & 0.24 \\
\hline
\end{tabular}

Note: All the coefficients are statistically significant at $p<0.001$ except at $* p<0.05 ; * * p<0.01$ Source: Authors' tabulations based on census samples from IPUMS-International

The numerator of Delta captures the actual increase in cohabitation in the observed 30 year period, whereas the denominator measures how far off the region still was at the onset from an upper maximum level, set here at $95 \%$ cohabiting. This upper limit is chosen arbitrarily, but taking into consideration that some Brazilian meso-regions are now already at about $80 \%$, and that in other Latin American countries, some regions have almost universal cohabitation among women 25-29.

The outcomes of the OLS regressions are displayed in Table 8.5 in the form of comparable standardized regression coefficients (betas). The complete regression results are given in the appendix Table 8.8 .

As indicated by the results for $\mathrm{r} 30$, the highest rates of increase are found in the areas with larger Catholic and white female populations. The percentages born outof-state and with secondary education produce no significant effects, whereas urban meso-regions exhibit slower rates of increase. The large standardized regression coefficients for percentages Catholics and Whites come as no surprise, since these areas had the lowest cohabitation incidence to start with and have the widest margins for subsequent catching up. This is indeed what is happening: when the initial levels of cohabitation measured as of 1980 are added, the standardized regression coefficients of percentages Catholic and white drop considerably, and most of the variance is explained by the level of cohabitation at the onset. The higher that level, the larger the denominator of $\mathrm{r} 30$, and hence the slower the relative pace of change.

Delta30, however, corrects for this artifact by dividing by the remaining gap between the level of 1980 and the level taken as that for a "completed" transition. Regions with higher levels at the onset are now at a greater advantage and get a bonus for still completing a portion of the remaining transition. The standardized regression coefficients for Delta30 indicate that the Catholic and the white mesoregions were on average closing relatively smaller portions of the remaining transition, and the same was also true for urban meso-regions. 
Hence, in terms of classic growth rates of cohabitation among partnered women 25-29, predominantly Catholic and white regions are exhibiting the expected catching up, but in terms of the portion covered of the amount of transition still left, these regions were not doing better than the ones which were further advanced to start with. In addition, urban meso-regions tended to move slower irrespective of the type of measurement of change. Much of this amounts to stating that the steady upward shift of the meso-regions, as depicted in Fig. 8.3, occurred rather evenly in all types of meso-regions, with the exception of a somewhat slower transition in the urban ones.

\section{Conclusions}

The availability of the micro data in the IPUMS samples for several censuses spanning a period of 40 years permits a much more detailed study of differentials and trends in cohabitation in Brazil than has hitherto been the case. The gist of the story is that the historical race/class and religious differentials and the historical spatial contrasts have largely been maintained, but are now operating at much higher levels than in the 1970s. During the last 40 years cohabitation has dramatically increased in all strata of the Brazilian population, and it has spread geographically to all areas in tandem with further expansions in the regions that had historically higher levels to start with. Moreover, the probability of cohabiting depends not only on individuallevel characteristics but also on additional contextual effects operating at the level of meso-regions. Furthermore, the progression over time shows both a clear cohortwise layering and a steady cohort profile extending over the entire life span until at least the ages of 50 and 60 . Hence, we are essentially not dealing with a pattern of brief trials of partnership followed by marriage, but with extended cohabitation.

The rise of cohabitation in Brazil fits the model of the "Second demographic transition", but it is grafted onto a historical pattern which is still manifesting itself in a number of ways. Social class and race differentials have not been neutralized yet, young cohabitants with lower education and weaker earning capacity can continue to co-reside with parents in extended households (cf. Esteve et al. 2012b), and residence in predominantly Catholic and white meso-regions is still a counteracting force.

All this is reminiscent of the great heterogeneity among countries, regions and social groups that emerged from the studies of the "First demographic transition", and especially from those focusing on the fertility decline. Then too, it was found that there were universal driving forces, but that there were many context- and pathspecific courses toward the given goal of controlled fertility. In other words, the local "sub-narrative" mattered a great deal. The same is being repeated for the "Second demographic transition" as well, and the Brazilian example illustrates this point just perfectly. 


\section{Appendix}

Table 8.6 Percent cohabiting among partnered women 25-29 in Brazil and Brazilian States, 1960-2010 censuses (IPUMS samples)

\begin{tabular}{l|l|l|l|l|l|l}
\hline & 1960 & 1970 & 1980 & 1991 & 2000 & 2010 \\
\hline Rondônia & - & 13.6 & 15.4 & 30.7 & 42.6 & 53.4 \\
\hline Acre & - & 11.0 & 18.8 & 44.6 & 60.0 & 61.1 \\
\hline Amazonas & - & 9.6 & 17.5 & 41.1 & 60.1 & 67.0 \\
\hline Roraima & - & 20.1 & 22.9 & 45.8 & 61.6 & 68.2 \\
\hline Pará & - & 19.0 & 22.2 & 38.3 & 58.9 & 70.4 \\
\hline Amapá & - & 20.6 & 23.6 & 45.1 & 68.7 & 76.2 \\
\hline Tocantins & - & - & - & 19.4 & 38.3 & 54.6 \\
\hline Maranhão & - & 13.6 & 19.2 & 28.5 & 48.3 & 64.7 \\
\hline Piaú́ & - & 4.0 & 4.2 & 11.9 & 27.6 & 44.8 \\
\hline Ceará & 2.48 & 3.4 & 7.3 & 17.9 & 35.7 & 50.4 \\
\hline Rio Grande do Norte & 5.99 & 6.2 & 9.6 & 22.2 & 46.2 & 60.2 \\
\hline Paraíba & 5.76 & 5.5 & 11.1 & 21.7 & 40.8 & 49.6 \\
\hline Pernambuco & 12.34 & 13.7 & 21.4 & 31.4 & 48.5 & 53.9 \\
\hline Alagoas & 10.35 & 11.1 & 16.6 & 28.2 & 46.0 & 53.5 \\
\hline Sergipe & 13.56 & 12.0 & 18.5 & 33.4 & 50.9 & 63.3 \\
\hline Bahia & 16.19 & 15.1 & 22.5 & 32.2 & 49.0 & 60.2 \\
\hline Minas Gerais & 3.08 & 3.7 & 7.1 & 13.6 & 26.0 & 37.7 \\
\hline Espírito Santo & - & 8.1 & 11.8 & 20.8 & 34.2 & 40.7 \\
\hline Rio de Janeiro & 12.60 & 13.9 & 22.6 & 32.0 & 45.1 & 52.6 \\
\hline Guanabara & - & 12.4 & - & - & - & - \\
\hline São Paulo & 2.57 & 4.3 & 10.3 & 17.6 & 34.8 & 43.4 \\
\hline Serra dos Aimorés & 5.17 & - & - & - & - & - \\
\hline Paraná & 2.49 & 3.1 & 7.0 & 13.6 & 28.9 & 43.4 \\
\hline Santa Catarina & - & 3.5 & 5.4 & 12.6 & 30.4 & 50.8 \\
\hline Rio Grande do Sul & 5.22 & 5.0 & 9.2 & 19.8 & 40.6 & 60.6 \\
\hline Mato Grosso do Sul & - & - & 18.1 & 28.2 & 45.2 & 53.6 \\
\hline Mato Grosso & 11.62 & 10.8 & 13.5 & 24.9 & 44.2 & 55.6 \\
\hline Goiás & 5.87 & 7.3 & 11.9 & 21.8 & 36.5 & 46.6 \\
\hline Distrito Federal & 3.90 & 8.5 & 14.8 & 28.2 & 42.0 & 50.0 \\
\hline Fernando de Noronha & 0.00 & - & 44.4 & - & - & - \\
\hline Total & 6.17 & 7.6 & 13.0 & 22.2 & 39.3 & 51.0 \\
\hline Sauce: Auth & & & & & & \\
\hline
\end{tabular}

Source: Authors' tabulations based on census samples from IPUMS-International

aThe 1960 total does not include the values of the states with no data 
Table 8.7 Estimated odds ratios from a multilevel logistic regression model of unmarried cohabitation among partnered women $25-29$ by social characteristics and types of meso-regions, Brazil 2000

\begin{tabular}{|c|c|c|c|c|c|c|}
\hline Variables/category & Model 1 & Model 2 & Model 3 & Model 4 & Model 5 & Model 6 \\
\hline \multicolumn{7}{|l|}{ Religion } \\
\hline Protestant Lutheran, Baptist & & -0.94 & -0.93 & -0.85 & -0.84 & -0.84 \\
\hline Evangelical & & -0.71 & -0.75 & -0.83 & -0.83 & -0.83 \\
\hline No religion & & 0.72 & 0.69 & 0.65 & 0.65 & 0.65 \\
\hline Others & & -0.17 & -0.14 & 0.11 & 0.12 & 0.12 \\
\hline Catholic (ref.) & & 0 & 0 & 0 & 0 & 0 \\
\hline \multicolumn{7}{|l|}{ Race } \\
\hline Black & & & 0.82 & 0.68 & 0.69 & 0.68 \\
\hline Brown Brazil & & & 0.51 & 0.39 & 0.38 & 0.38 \\
\hline Indigenous & & & 0.90 & 0.75 & 0.76 & 0.76 \\
\hline Others & & & 0.15 & 0.17 & 0.18 & 0.18 \\
\hline White (ref.) & & & 0 & 0 & 0 & 0 \\
\hline \multicolumn{7}{|l|}{ Education } \\
\hline Less than Secondary & & & & 1.40 & 1.39 & 1.39 \\
\hline Secondary & & & & 0.54 & 0.54 & 0.54 \\
\hline University (ref.) & & & & 0 & 0 & 0 \\
\hline \multicolumn{7}{|l|}{ Migrant } \\
\hline Residence in another State & & & & & 0.24 & 0.24 \\
\hline Residence in State of birth (ref.) & & & & & 0 & 0 \\
\hline \multicolumn{7}{|l|}{ Types of meso-regions } \\
\hline $\begin{array}{l}\text { Catholic - No White - No } \\
\text { Secondary (Cws) }\end{array}$ & & & & & & 0.11 \\
\hline $\begin{array}{l}\text { Catholic - No White - } \\
\text { Secondary (CwS) }\end{array}$ & & & & & & 0.75 \\
\hline $\begin{array}{l}\text { Catholic - White - No } \\
\text { Secondary (CWs) }\end{array}$ & & & & & & 0.12 \\
\hline $\begin{array}{l}\text { No Catholic - No White - No } \\
\text { Secondary (cws) }\end{array}$ & & & & & & 0.88 \\
\hline $\begin{array}{l}\text { No Catholic - No White - } \\
\text { Secondary (cwS) }\end{array}$ & & & & & & 1.30 \\
\hline $\begin{array}{l}\text { No Catholic - White - No } \\
\text { Secondary (cWs) }\end{array}$ & & & & & & 0.30 \\
\hline $\begin{array}{l}\text { No Catholic - White - } \\
\text { Secondary (cWS) }\end{array}$ & & & & & & 0.46 \\
\hline $\begin{array}{l}\text { Catholic - White - Secondary } \\
\text { (CWS) (ref.) }\end{array}$ & & & & & & 0 \\
\hline Meso-regions variance & 0.32 & 0.34 & 0.30 & 0.34 & 0.32 & 0.19 \\
\hline Intercept & -0.50 & -0.41 & -0.68 & -1.82 & -1.85 & -2.26 \\
\hline
\end{tabular}

Note: All regression coefficients are statistically significant at the 0.0001 level

Source: Authors' tabulations based on census samples from IPUMS-International 
Table 8.8 Full OLS regression results of the three models predicting the change in percentages cohabiting among partnered women between 1980 and 2010 in 136 Brazilian meso-regions

\begin{tabular}{l|l|l|l|l|l|l}
\hline Variable & DF & $\begin{array}{l}\text { Parameter } \\
\text { Estim. }\end{array}$ & $\begin{array}{l}\text { Standar } \\
\text { Error }\end{array}$ & t value & $\operatorname{Pr}>|\mathrm{t}|$ & $\begin{array}{l}\text { Parameter } \\
\text { standardized }\end{array}$ \\
\hline
\end{tabular}

(a) $\mathrm{r} 30=\ln$ (Coha 2010/Coha 1980), results without control for initial cohabitation level.

Rsq $=0.650$

\begin{tabular}{l|l|r|l|r|l|l}
\hline Intercept & 1 & -0.98518 & 0.3728 & -2.64 & 0.009 & 0 \\
\hline Catholic & 1 & 3.47761 & 0.34453 & 10.09 & $<.0001$ & 0.657 \\
\hline White & 1 & 0.9691 & 0.153 & 6.33 & $<.0001$ & 0.422 \\
\hline Secondary & 1 & 0.96482 & 1.08298 & 0.89 & 0.375 & 0.120 \\
\hline Migrant & 1 & 0.27356 & 0.22425 & 1.22 & 0.225 & 0.071 \\
\hline Urban & 1 & -1.04587 & 0.4321 & -2.42 & 0.017 & -0.317 \\
\hline
\end{tabular}

(b) r30, results with initial cohabitation level of 1980 (Coha 1980). Rsq=0.845

\begin{tabular}{l|l|l|l|l|l|l}
\hline Intercept & 1 & 1.5852 & 0.31962 & 4.96 & $<.0001$ & 0 \\
\hline Catholic & 1 & 1.15925 & 0.2926 & 3.96 & 0.000 & 0.219 \\
\hline White & 1 & 0.25654 & 0.11627 & 2.21 & 0.029 & 0.112 \\
\hline Secondary & 1 & 0.47144 & 0.72378 & 0.65 & 0.516 & 0.059 \\
\hline Migrant & 1 & -0.09826 & 0.15245 & -0.64 & 0.520 & -0.026 \\
\hline Urban & 1 & -0.7088 & 0.28957 & -2.45 & 0.016 & -0.215 \\
\hline Cohabitation 1980 & 1 & -4.33242 & 0.33818 & -12.81 & $<.0001$ & -0.679 \\
\hline
\end{tabular}

(c) Delta30 $=($ Coha 2010-Coha 1980$) /(0.950-$ Coha 1980). Rsq $=0.239$

\begin{tabular}{l|l|r|l|r|l|c}
\hline Intercept & 1 & 0.8854 & 0.12543 & 7.06 & $<.0001$ & \multicolumn{1}{c}{0} \\
\hline Catholic & 1 & -0.17619 & 0.11592 & -1.52 & 0.131 & -0.146 \\
\hline White & 1 & -0.13537 & 0.05147 & -2.63 & 0.010 & -0.259 \\
\hline Secondary & 1 & 0.07723 & 0.36437 & 0.21 & 0.833 & 0.042 \\
\hline Migrant & 1 & 0.00421 & 0.07545 & 0.06 & 0.956 & 0.005 \\
\hline Urban & 1 & -0.27755 & 0.14538 & -1.91 & 0.058 & -0.369 \\
\hline
\end{tabular}

Note: Covariates measured in 2000 as percentages for women 25-29 in each meso-region Source: Authors' tabulations based on census samples from IPUMS-International

Open Access This chapter is distributed under the terms of the Creative Commons AttributionNonCommercial 4.0 International License (http://creativecommons.org/licenses/by-nc/4.0/), which permits any noncommercial use, duplication, adaptation, distribution and reproduction in any medium or format, as long as you give appropriate credit to the original author(s) and the source, provide a link to the Creative Commons license and indicate if changes were made.

The images or other third party material in this chapter are included in the work's Creative Commons license, unless indicated otherwise in the credit line; if such material is not included in the work's Creative Commons license and the respective action is not permitted by statutory regulation, users will need to obtain permission from the license holder to duplicate, adapt or reproduce the material. 


\section{References}

Banco Central do Brasil. (2009). Evolução do IDH das Grandes Regiões e Unidades da Federação. Boletim Regional do Banco Central do Brasil, Janeiro.

Borges, D. E. (1994). The family in Bahia, Brazil, 1870-1945. Stanford: Stanford University Press. Also excerpted in eHRAF World Cultures.

Brazil, Código Civil, 2002 (Civil Code).

Corrêa, M. (1993). Repensando a família patriarcal brasileira: notas para o estudo das formas de organização familiar no Brasil. In M. Corrêa (Ed.), Colcha de retalhos: estudos sobre a família no Brasil. Campinas: Editora da Unicamp.

Covre-Sussai, M., \& Matthijs, K. (2010). Socio-economic and cultural correlates of cohabitation in Brazil. Paper presented at the 2010 Chaire Quételet Conference, Louvain-la-Neuve.

de Almeida, A. M. (1987). Notas sobre a família no Brasil. In A. M. de Almeida et al. (Eds.), Pensando a familia no Brasil: da colônia à modernidade (pp. 53-66). Rio de Janeiro: Espaço e Tempo. ISBN 8585114207.

de Alzevedo, T., Beierle, J. B., Edward, D. et al. (1999). Bahian Brazilians. eHRAF World Cultures. Yale University Human Relations Area files (electronic version: http://ehrafworldcultures.yale. edu/ehrafe/browseCultures.do?owc=SO11\#owc)

de Mesquita Samara, E. (1987). Tendencias atuais da historia da familia no Brasil. In A. M. Almeida et al. (Eds.), Pensando a familia no Brasil (pp. 25-36). Rio de Janeiro: Espaço e Tempo.

de Mesquita Samara, E. (1997). A família no Brasil: história e historiografia. História Revista, Goiânia, 2(2), 7-21.

de Mesquita Samara, E. (2002). O que mudou na família brasileira? (Da Colônia à atualidade). Psicologia USP, 13(2), 27-48.

Instituto Brasileiro de Geografia e Estatística. (2012). Síntese de indicadores sociais 2012. Uma análise das condições de vida da população brasileira. Rio de Janeiro: IBGE, Estudos e Pesquisas. Informação demográfica e socioeconômica, Vol. 29.

Instituto Brasileiro de Geografia e Estatística. (2013). Banco de Dados Agregados. Sistema IBGE de Recuperação Automática - SIDRA. Available in: www.ibge.gov.br

Esteve, A., Lesthaeghe, R., \& López-Gay, A. (2012a). The Latin American cohabitation boom, 1970-2007. Population and Development Review, 38(1), 55-81.

Esteve, A., Garcia-Román, J., \& Lesthaeghe, R. (2012b). The family context of cohabitation and single motherhood in Latin America. Population and Development Review, 38(4), 699-719.

Freyre, G. (1933). Casa grande e senzala: formação da família brasileira sob o regime de economia patriarcal. 41st edition reprinted in 2000. Rio de Janeiro: Record.

Goody, J. (1976). Production and reproduction. A comparative study of the domestic domain. Cambridge: Cambridge University Press. ISBN 9780521290883.

Guimarães Neto, L. (1998). Ciclos econômicos e desigualdades regionais no Brasil. Cadernos de Estudos Sociais, 14(2), 315-342.

Holt, K. (2005). Marriage choices in a plantation society: Bahia, Brazil. International Review of Social History, 50(Suppl S13), 25-41.

IPEA. (2010). Dimensão, Evolução e Projeção da Pobreza por Região e por Estado no Brasil. Comunicados do Ipea, 58. Brasília: Governo Federal. Secretaria de Assuntos Estratégicos da Presidência da República.

Lesthaeghe, R. (2010). The unfolding story of the second demographic transition. Population and Development Review, 36(2), 211-252.

Minnesota Population Center. (2014). Integrated Public Use Microdata Series (IPUMS). version 6.3. Minneapolis: University of Minnesota.

Nogales Vasconcelos, A. M., \& Forte Gomes, M. M. (2012). Transição demográfica: a experiência brasileira. Epidemiologia e Serviços de Saúde, 21(4), 539-548.

Quilodrán, J. (1999). L'union libre en Amerique latine: aspects récents d'un phénomène séculaire. Cahiers Québécois de Démographie, 28(1-2), 53-80. 
Quilodrán, J. (2008). A post-transitional nuptiality model in Latin America? Paper presented at the International seminar on changing transitions to marriage, New Delhi, India, 10-12 September. Ribeiro, D. (1995). O povo brasileiro: a formação e sentido do Brasil. São Paulo: Companhia das Letras.

Roberts, G. W., \& Sinclair, S. A. (1978). Women in Jamaïca. Patterns of reproduction and family. New York: KTO Press.

Rodríguez Vignoli, J. (2005). Unión y cohabitación en America Latina: modernidad, exclusión, diversidad. Santiago de Chile: CELADE, Division de Poblacion de la CEPAL and UNFPA, Serie Poblacion y Desarrollo 57.

Smith, R. T. (1956). The negro family in British Guyana. Family structure and social status in the villages. London: Routledge \& Kegan Paul.

Vidal Souza, C., \& Rodrigues Botelho, T. (2001). Modelos nacionais e regionais de família no pensamento social brasileiro. Estudos Feministas, 415(2), 414-432. 